\title{
CONTRIBUTION OF LIVE WORKING TO THE QUALITY, SAFETY, EFECTIVENESS AND EFFICIENCY OF THE MAINTENANCE PROCESSES
}

\author{
Viktor Lovrenčić, Alenka Brezavšček, Miloš Pantoš, Boštjan Gomišček
}

Subject review

In spite of the fact that live working has been carried out in the world for over a hundred years, it has been used in Slovenia as a tool of preventive maintenance of electrical installations only for the last few years. Live working is a novelty for the Slovene electricity environment, so it deserves professional and scientific attention. A review of secondary sources shows that there are many professional sources mainly covering the narrow field of the development of live working technology, equipment and tools, personal protective equipment and training in live working. This review of the literature presents the area of live working where its possibilities for a broader use are offered. The analysis of live working effects is presented under the integration of corrective and preventive maintenance as well as the concepts of health and safety at work, quality, effectiveness and efficiency of the live working method.

Keywords: effectiveness; efficiency; live working; maintenance; quality; safety

Doprinos rada pod naponom kvaliteti, sigurnosti, uspješnosti i učinkovitosti procesa održavanja

Pregledni članak

Unatoč činjenici da se rad pod naponom provodi u svijetu već više od stotinu godina, u Sloveniji se kao sredstvo preventivnog održavanja električnih instalacija koristi tek u posljednjih nekoliko godina. Rad pod naponom je novost za slovensko elektroenergetsko okruženje tako da zaslužuje stručnu i znanstvenu pozornost. Pregled sekundarnih izvora na tom području pokazuje da postoje mnogi izvori, koji uglavnom pokrivaju usko područje razvoja tehnologije rada pod naponom, opreme i alata te osobne zaštitne opreme i obuku za rad pod naponom. Sa pregledom literature smo predstavili područje rada pod naponom gdje se otavaraju mogućnosti njegove uporabe i analize učinaka rada pod naponom kod integracije u kurativno i preventivno održavanje te koncepte sigurnosti i zdravlja na radu, kvalitete te uspješnosti i učinkovitosti metode rada pod naponom.

Ključne riječi: kvaliteta; održavanje; rad pod naponom; sigurnost; učinkovitost; uspješnost

\section{Introduction}

The live working (LW) development has a hundred year tradition in the world [1]. As early as in 1913 the first carrying out of live working in the world was documented in the USA [2], in Europe in 1933 - in Poland [3] and in 1963 in France [1]. In Slovenia, carrying out of live working began only in 2009 [4].

In spite of the long tradition live working has been given incentives for further development. Traditionally, the development of live working is related to the increase in the voltage level of electricity transmission, which requires the research of new live working methods at high voltage (HV) and ultrahigh voltage (UHV) levels, the development of new personal protective equipment and materials for tools and equipment from numerous institutes [5].

The recent professional, specialised conferences on live working confirm the current relevance of the live working development at all voltage levels (IEEE ESMO, 2011; CITTES, 2013; ICOLIM, 2014). The actuality of live working use is proved also in the CIGRE technical brochure, prepared by the working team SC B2/B3 JWG27 "Live Working - A Management Perspective", with the ambition to offer a tool to the management of transmission operators and distribution networks for the introduction of live working on $\mathrm{HV}$ and UHV installations [5].

The deregulation of the electricity market, especially in the European Union, posed new challenges to the transmission and distribution networks in the last decade. By the liberalisation of the electricity market the live working has gained a new incentive. By the increase in the number of participants in the market and by clear economic requirements the pressure of national regulations on the transmission and distribution networks has been intensified. It is a task of the regulator to establish the conditions for the development of competitiveness and provision of its functioning taking into account the requirements for durable, reliable and quality supply and for the achievement of higher standards of quality of electricity and/or the quality of electricity supply [6].

The purpose of the paper is the literature review that deals with live working, especially that published in the recent period. On the basis of the literature review we would like to present and point out that there is a disproportionate small number of publications about the research of advantages that live working offers in various fields related to the organisation of maintenance and/or introduction of new maintenance concepts, quality management, health and safety at work, quality of electricity supply service and the efficiency and effectiveness of live working in the maintenance of distribution networks and/or electrical installations.

\section{Frameworks and limitations of the research}

The development and events in the organisations that carry out live working are monitored by numerous interested parties: the management and the employees within an organisation, as well as external stakeholders, possible investors, electricity consumers, suppliers of technology for carrying out live working and the tools and equipment, institutions (institutes, training centres), professional civil organisations (standardisation), competition in the market of live working services, narrow and broad community (ministries for industry and 
labour, national energy regulators and/or agencies, labour inspectors, trade unions, international civil professional associations) [5].

The in-depth examination of programmes and/or papers from professional conferences (IEEE ESMO: 1993 to 2011; CITTES: 2003 to 2013; ICOLIM: 1992 to 2014) shows that experts from all over the world discuss live working mostly from the aspects of development of technology and methods of live working at all voltage levels, development of tools and equipment and training of fitters.

Table 1 Survey of ICOLIM research papers published from 1992 to 2014

\begin{tabular}{|c|c|c|c|c|c|c|c|c|}
\hline ICOLIM & Place & ALL & ТЕСH & $\mathbf{Q M}$ & QES & H\&S & TRA & $\mathbf{E \& E}$ \\
\hline 1992 & Keszthely, HU & 42 & 39 & 0 & 0 & $1(4)$ & 0 & $2(3)$ \\
\hline 1994 & Mulhouse, FR & 37 & 26 & $3(3)$ & $0(2)$ & $3(5)$ & 3 & $2(4)$ \\
\hline 1996 & Venice, IT & 39 & 34 & 1 & 3 & $0(4)$ & 1 & $0(1)$ \\
\hline 1998 & Lisbon, PT & 55 & 46 & $4(1)$ & 0 & $4(1)$ & 0 & $1(5)$ \\
\hline 2000 & Madrid, ES & 70 & 62 & $2(1)$ & 0 & $5(7)$ & $1(1)$ & $0(5)$ \\
\hline 2002 & Berlin, DE & 55 & 50 & 1 & 0 & $2(3)$ & 0 & $2(2)$ \\
\hline 2004 & Bucharest, RO & 66 & 63 & 0 & $0(3)$ & $0(5)$ & $2(3)$ & $1(5)$ \\
\hline 2006 & Prague, $\mathrm{CZ}$ & 54 & 51 & $1(2)$ & $1(1)$ & $0(5)$ & $1(4)$ & $0(4)$ \\
\hline 2008 & Torun, PL & 65 & 60 & $0(2)$ & $1(2)$ & $0(3)$ & $2(1)$ & $2(3)$ \\
\hline 2011 & Zagreb, HR & 57 & 44 & 2 & 0 & $0(2)$ & $11(1)$ & $0(2)$ \\
\hline \multirow[t]{2}{*}{2014} & Budapest, HU & 69 & 53 & $1(1)$ & $1(3)$ & $1(3)$ & $9(2)$ & $4(1)$ \\
\hline & TOTAL: & 579 & 498 & $15(10)$ & $6(11)$ & $16(42)$ & $30(12)$ & $14(35)$ \\
\hline
\end{tabular}

NOTE: ALL = all research papers; TECH = Live working technology; QM = Quality management; QES = Quality of electricity supply (SAIDI and SAIFI indicators); H\&S = Health and safety at work (accidents at work); TRA = Training, E\&E = effectiveness and efficiency (E\&E indicators). Interpretation: e.g. QM 15(10) $=15$ research papers deal with the QM topic as a priority while 10 only partially (it is not the core topic).

When reviewing literature it should be emphasised that some limitations are imposed by public accessibility of the studies and statistical data in individual countries. The owners of studies and analyses, mostly done for transmission and distribution networks and their contractors (institutes), protect their copyrights, creating thereby a huge research gap.

The correctly selected key words entered into the online search machine produce thousands of results and provide many sources on live working. The "International Conference on Live Maintenance - ICOLIM 2014, Budapest", organised by the Live Work Association (LWA), contributed a valuable collection of all research papers from the first conference in 1992 to the 11th in 2014. A detailed survey of 579 research papers of all eleven ICOLIM conferences reveals that the topics on quality, safety, effectiveness and efficiency of live working are only rarely presented (Table 1).

\section{Historical development of live working}

Live working is considered each work where a worker knowingly touches live parts with the parts of the body or a tool, equipment or devices, or comes close to the live working area [7].

The definitions from the standard have been summarised here for the appropriate understanding of the terms relating to live working [7]. There are three recognised methods of work distinguished by the position of a worker with respect to the live parts and by the equipment used for the protection against an electric shock and short-circuit. They are:

- Hot stick working - Safe clearance working,

- Insulating glove working,

- Bare hand working.

In 1913, the event when a fitter used a raw wood stick (disconnect stick) in the medium voltage network in Ohio, USA or the use of the insulation wood stick (hot stick) marks the official beginning of live working in literature $[1,2,8]$.

Researchers and experts from various fields have searched for arguments for the introduction and use of live working as a tool of preventive maintenance on electrical installations of all voltage levels for a hundred years [9].

At the ICOLIM 2014 conference we were informed about two European anniversaries of carrying out live working - the $80^{\text {th }}$ anniversary in Poland [3] and the $50^{\text {th }}$ anniversary in France [10].

The majority of sources mention the history of the development only as fragments and therefore a complete survey and development of live working in France is worth mentioning, and it has been published in the book [1].

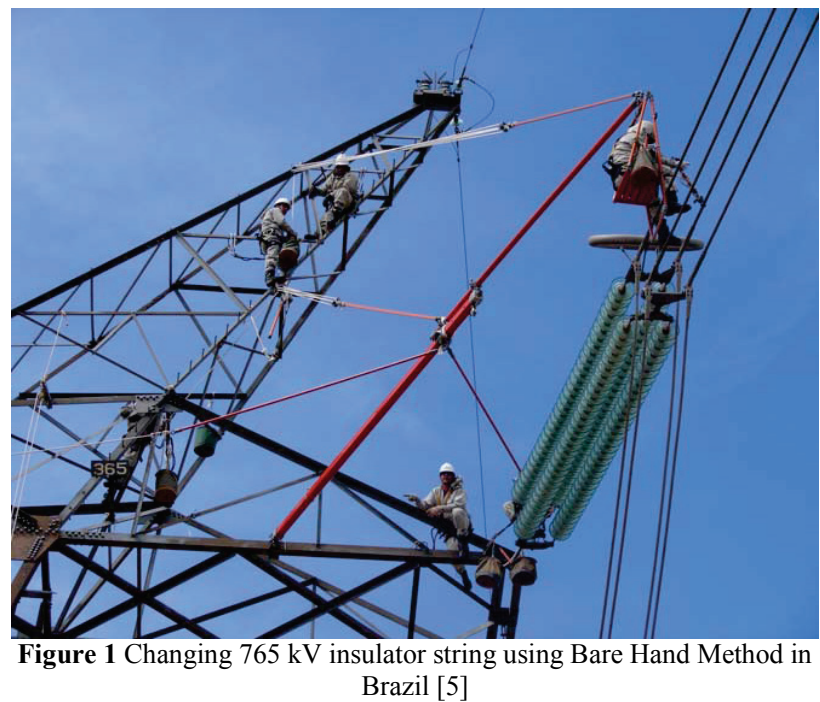

Live working on the potential has opened up new dimensions of the maintenance of overhead power lines and substation $(\mathrm{S} / \mathrm{S})$. Nowadays, this is the most suitable method for $\mathrm{HV}$ and UHV devices (from $400 \mathrm{kV}$ to 
$765 \mathrm{kV})$. The access to the potential is possible from the ground by insulation ladders (Fig. 1) and by the use of insulation ropes, insulation baskets or platforms that are lifted by ropes or a mobile crane (a hydraulic telescopic basket has an insulator installed in the body of the pole of an adequate length, depending on the voltage of live working carrying out).

The use of a helicopter offers new opportunities for live working on the potential in the countries with large distances of overhead power lines (USA, Canada, France, Germany, Great Britain, etc.) as the helicopter can take a fitter in a basket or on a platform to the place of carrying out of live working [11].

The experts have initiated a discussion on the type of technological novelties from the increasingly frequent use of a helicopter and truck platforms for cleaning of $\mathrm{HV}$ equipment $[12,13]$, specialist solutions, such as the use of robots [14] and basic research of materials and their behaviour in an electro-magnetic field [15], testing of personal protective equipment, such as protection of eyes and face against electric arc [16] and impacts of electricity and an electro-magnetic field on a human being [17].

Live working with insulation gloves or "in contact" that has been developed as practically the only method for work on low voltage (LV) electrical installations [18] has been taken over by the Slovene electricity industry on the basis of the contract concluded between C\&G d.o.o. Ljubljana and the Croatian specialised training centre HEP NOC, Velika in 2007. HEP NOC took over the know-how and the live working procedures on LV installations from SERECT. The maintenance of LV electrical installations by live working started in Slovenia in January 2009 in the Nuclear Power Plant Krško, when the first Slovene maintainers obtained all the necessary licences for live working on LV installations [4] and in 2011 for live working in the Slovene distribution [19] after a year of a detailed introduction of the live working system and training.

\section{Live working as a tool of preventive maintenance}

The complexity of live working organisation as a service of preventive maintenance of electrical installations is illustrated by the definition of electrical installations: "the electrical installations comprise the installations and electrical equipment for the production, transmission, transformation, distribution and consumption of electricity" [7].

The global and Slovene experts and professionals who research, and apply different maintenance tools and procedures consider the maintenance as an increasingly important function that has played a crucial role in the organisations [20].

The maintenance is a combination of all technical and administrative activities including inspections, monitoring and supervision over the products, machines or processes with the aim to keep or re-establish such conditions that help us achieve their required functionality [21].

Preventive maintenance can be defined as one of the key tasks of the decision-making process of the management. It is necessary to establish an adequate "system": objective - symptom - sensor (signal) - signal processing - monitoring of the conditions - diagnosis prognosis - decisions - maintenance intervention providing quality and timely data for taking decisions so that the means of work will achieve the required characteristics and availability [20].

Preventive maintenance (PM) approach can be in general divided into [20]:

- $\quad$ TBM - Time Based Maintenance,

- CBM - Condition Based Maintenance,

- PdM - Predictive Maintenance,

- $\quad$ PaM - Proactive Maintenance.

If the definition of preventive maintenance is considered, it is logical that live working is classified as a tool of preventive maintenance of electrical installations, because the basic objective of live working is the maintenance of electrical installations and/or equipment without the interruption in the electricity supply to households, institutions and industry or internal consumers [19].

$\mathrm{PdM}, \mathrm{PaM}$, and $\mathrm{CBM}$ are the maintenance concepts based on the decisions on the maintenance based on the data gathered by monitoring the conditions. It consists of three main steps: capture of data, data processing and decision-making on maintenance interventions [20]. Live working offers an excellent tool which enables the improvement in time and cost components of maintenance intervention.

Reliability Centred Maintenance (RCM) combines several known techniques and tools for the achievement of efficient and successful decisions in the field of maintenance, where RCM pursues the three main objectives: increase in safety and reliability of the system, prevention of consequences of failures and reduction in the costs of maintenance [20]. Live working fully supports and enables the achievement of these objectives.

Total Productive Maintenance (TPM) is a system for the production management that was developed in the 70's in Japan and presented by Nakajima [22]. Live working can be integrated into TPM from the aspect of continuous improvements, team work, improvement in quality and efficiency of production and maintenance processes.

Total Quality Maintenance (TQMain) was presented as an idea by Al-Najjar [21], as he developed the TQMain as the concept of industrial maintenance that includes adequate methods, techniques and strategies. When discussing maintenance in production - e.g. in paper production [21] it is reasonable to join the research and developments about the increase in profitability and competitiveness of the organisation - e.g. by the use of condition-based integrated maintenance by means of measuring paper machine vibrations - the VibrationBased Maintenance model (VBM) based on new experience and by the use of the live working method in the maintenance of the PS5 paper machine in the Papirnica Vevče (Paper Mill) [23].

It can be concluded that the companies that carry out live working as a tool integrated in the concepts and programmes of preventive maintenance of electrical installations, achieve their objectives in an easier way, more effectively and efficiently, and gain advantages that 
are introduced by modern concepts of preventive maintenance (CBM, RCM, TPM, TQMain).

The analysis of modest Slovene experience in carrying out live working on LV installations in different environments (nuclear power plant, thermal or hydroelectric power plants, solar power plants, in transmission or distribution, in paper industry or production of pharmaceuticals or a medical centre) shows that several different organisational forms with a varying number of human resources and equipment and scope of maintenance and/or priorities in providing reliability and safety of continuous electricity supply have been developed in a short period [4, 19, 23, 25, 36].

\section{$4 \quad$ Live working and quality}

Portillo [24] discusses live working as an interdisciplinary or complex activity and opens new aspects of live working, as other authors see live working only through the prism of technology development, live working methods and/or development of tools and personal protective equipment and specialist training in live working.

The integration of live working into the quality management system ISO 9001 or into the integrated management system ISO 9001 and OHSAS 18001 (and other standards), the implementation of the PDCA cycle and the external and internal periodical inspection and/or audits of the systems and live working procedures provide a high standard of carrying out live working, contractor competence, quality tools and equipment as well as health and safety at work [25].

Lovrenčić and Oman [25] explained that the experts in 13 Slovene companies who already carried out live working, focused on the fulfilment of legal commitments and the amendments to the statement on safety with the risk assessment and the selection of the live working system and working procedures that have to be determined and verified in advance. Only 4 companies have completed the process of introducing live working by the upgrade of the quality management system ISO 9001.

Before the market liberalisation different criteria for the quality of electricity were applied to the transmission and distribution networks. One of the important criteria was the number of disconnections per year per $100 \mathrm{~km}$ of lines, unsupplied electricity and reliability of supplies. It is interesting to study the requirements for the quality of electricity, when the stability of the transmission system relating to the safe and economic operation of nuclear power plants in Belgium is concerned that set the conditions of carrying out live working in the maintenance [26].

The case of Spanish transmission recorded the positive statistics of non-availability transmission lines that declined in the period from 1986 to 1991, from $1.98 \%$ to $1.28 \%$, mostly due to the increase in carrying out live working in the networks. In the last ten years, a $10 \%$ improvement in the availability was achieved due to live working maintenance and a decrease in the number of hours of disconnections per year per $100 \mathrm{~km}$ of networks [27].
The transition from the old system of statistical monitoring of quality of electricity (e.g. the number of faults per year per $100 \mathrm{~km}$ of network) to the new one started ten years ago. Nowadays, the quality of electricity is an important criterion, mostly measured upon the reliable supply and/or continuous electricity supply. For example, the Hungarian analysis of the impact of live working on the quality of electricity is interesting, as the new MEH regulation was adopted (MEH - Hungarian energy regulator) in 2003 that introduced penalties for the non-achievement of the prescribed standards upon the transition to the open electricity market. The analysis has established that distributors can avoid the payment of penalties by the application of live working [28].

Public agencies and/or regulators at the level of the state or the EU annually report on the electricity quality indicators. The Council of European Energy Regulators (CEER) regularly submits benchmarking reports on electricity quality indicators. The most important indicators of electricity quality in the distribution networks included in the CEER [29] reports are:

- System Average Interruption Duration Index

(SAIDI),

- System Average Interruption Frequency Index (SAIFI).

It points out the great differences in the method of data acquisition, calculation and presentation of indicators (Fig. 2)

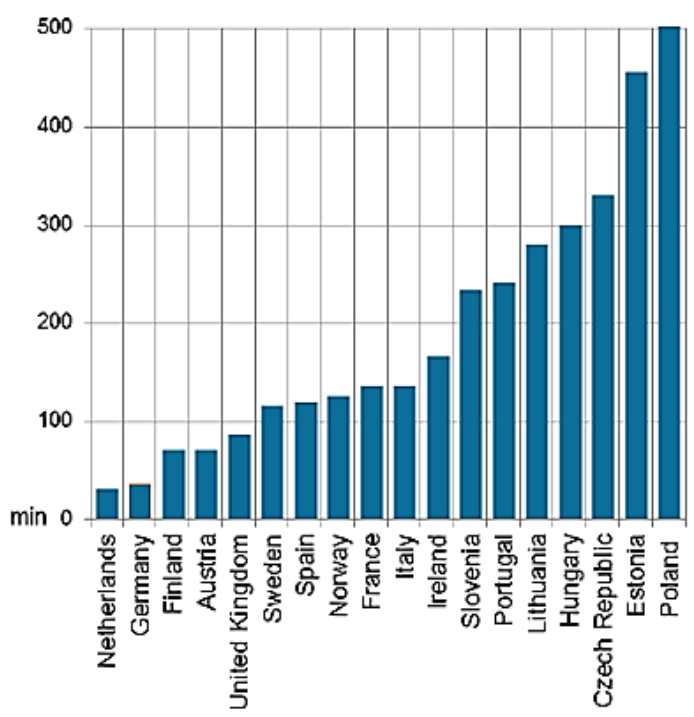

Figure 2 SAIDI indicators from the latest report of CEER [6]

A paper on the results of live working at low voltage (LV) and medium voltage (MV) levels in the distribution network owned by company E.on is of high interest [6].

The German energy regulator laid down clear and strict criteria for the achievement of the prescribed standards of quality of electricity for over 200 distribution networks. It is written in the conclusion of the paper [6] that E.on could not have reached the required level of electricity quality prescribed by the German energy regulator without the use of live working at the LV and MV levels (Fig. 3) 


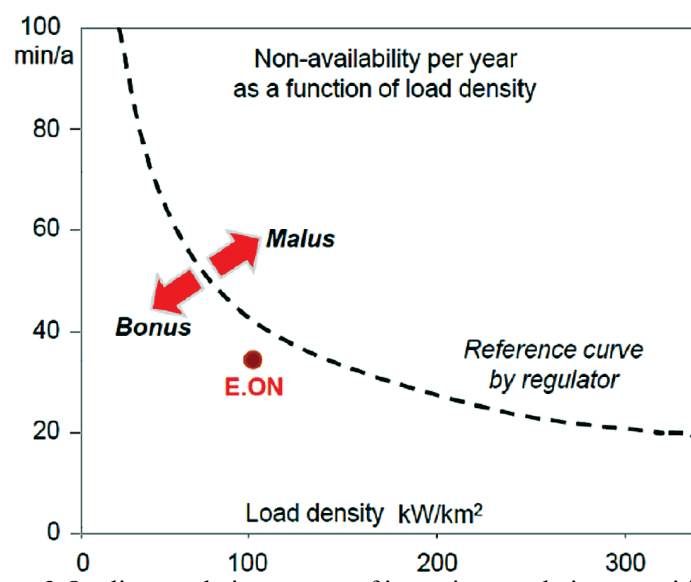

Figure 3 Quality regulation as part of incentive regulation - position of E.on [6]

Meeting of the needs of internal customers is of essential importance in the processing industry, as it provides the continuous production process - e.g. of paper or pharmaceuticals where a controlled and continuous process is a guarantee of the product quality. Electricians, maintainers of paper machines [23] or machines and/or equipment in pharmaceutical industry carrying out live working assure internal customers (production) a smooth process which has an impact on the decreased rejects and quality of a product.

\section{$5 \quad$ Live working and safety at work}

In practice, electricians use three working processes for the maintenance of electrical installations: work in a de-energised condition, live working and work in the proximity of energised elements based on the use of safety measures as protection against an electric shock and/or the effects of a short-circuit and electric arc [7].

We have thoroughly studied the records on the accidents caused by live working. After having reviewed over a hundred sources (e.g. ICOLIM, 1992-2014; IEEE ESMO 1993-2011) dealing with live working, we established that only old records on accidents due to live working were available.

Mrakovčić [30] analysed the UNIPEDE survey for the period 1978-1979 and established that UNIPEDE had many problems to obtain answers about accidents caused by live working. He establishes that over 50,000 electricians carried out live working at that time in Europe and that anonymous responses to the survey reported 171 accidents and 5 deaths when carrying out live working.

We obtained an original UNIPEDE report from Poland [31] that deals with the carrying out of live working in a complex manner (live working method, training, equipment and tools, organisation of work and accidents). The report discusses fatal and other accidents at work in the de-energised condition, live working on LV installations and accidents during live working on $\mathrm{HV}$ networks. Accidents in the de-energised condition were more frequent than accidents during live working in the period 1978-1989.

Dudek et al. [32] write that no accidents have been caused by live working in Poland since 1975, although several thousands of maintenance projects have been implemented.
Moreno and Viadas [33] analysed the accidents in company IBERDROLA, Spain, in the period 1992-1999 and established that live working on LV installations was safer than the work in the de-energised condition. They also made an analysis of arc-flash accidents and pointed out that more attention should have been paid to the selection of personal protective equipment and clothing.

The description of problems relating to carrying out live working at a safe distance on the overhead voltage of $500 \mathrm{kV}$ points out a possible accident at working at distance. Two events were described that occurred in the company Manitoba Hydro (Winnipeg, Canada) in 1997 and 2002, when an arc flash between a conductor and a fitter replacing an insulator caused an accident during live working at a safe distance. Burns on the arms of the fitter started an in-depth analysis of the event. Its purpose was an introduction of a corrective measure improving the live working procedures (periodic testing of voltage strength of the insulation rod, non-flammable material for working clothes) [34].

How difficult it is to discuss the problems of accidents relating to live working, especially from the aspect of collecting the accurate data, was presented by a quotation of the study [35]. The study of the STRI Scandinavian institute discusses the introduction of live working to the transmission North-European network and analyses in detail the experience in twenty countries of the world and establishes that "the problems and accidents are not mentioned in the available literature on live working" [35].

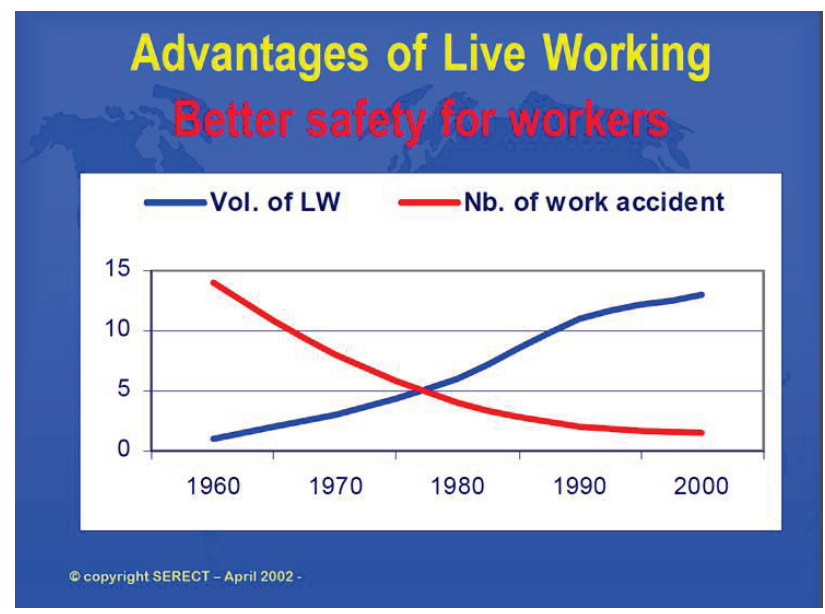

Figure 4 Advantages of LW, Better Safety for workers in France [36]

Lovrenčič and Gomišček [36] studied and presented the statistics of accidents caused by an electric shock. They pointed out that it is practically impossible to distinguish between accidents in a de-energised condition and the live working accidents, as the official statistics does not present them separately. The diagram, obtained from RTE SERECT, (Fig. 4) provides a valuable example of a trend of growth in carrying out live working lasting for several years and a decreasing trend of accidents at work in France during the period 1960-2000.

One of the leading contractor companies Quanta Energized Services (QES) from the USA points out a safety record - i.e. 4,600,000 working hours without any accidents during live working. QES emphasises that planning and carrying out are of key importance for a safe 
working environment. QES maintains a zero tolerance when the safety policy is concerned. Along with the regular annual re-certification of the safety system a special emphasis was placed on the obligatory training of all the employees in specific safety and urgent procedures [37].

\section{Live working and effectiveness and efficiency}

Live working as a method of maintenance of electrical installations has an impact on the effectiveness and efficiency of various organisations that produce, transmit, transform, distribute and consume electricity, or carry out live working as a service [5].

At the beginning of 1990's the unsupplied electricity had a strong impact on the calculation of effectiveness and efficiency of live working, as the revenue from the sale of electricity was a portion of the revenue from transmission and distribution networks at that time [37].

The reasoning of Électricité de France (EDF) is interesting as it says that the costs of unsupplied electricity have to be considered in addition to the costs of fuel in electric power plants because of the disconnections of transmission lines [38] or in Belgium, when a production outage in a nuclear power plant was estimated to amount to USD 30,000/100 MW/day [39].

The technology of carrying out live working can have an impact on the effectiveness and efficiency of live working. Antoine [40] found out that an average disconnection was shortened from three hours in the year 1974 to only 46 minutes in the year 1990 by the introduction of live working and new technologies of live working in France. On request of the distribution company SERECT started to develop the combined live working method named C3M after the year 1983. The $\mathrm{C} 3 \mathrm{M}$ method integrated all three basic methods relating to a contact, distance and potential. Carrying out of live working was more efficient by the $\mathrm{C} 3 \mathrm{M}$ method, as the duration of individual standard works shortened by $15 \%$ to $50 \%$ over the classical methods of live working.

The German experience of the impact of live working on SAIDI and SAIFI has shown excellent results, namely by the calculation of possible penalties and benefits that the incentive scheme brings [6].

The formula of the incentive scheme includes also the impact of planned disconnections and thereby carrying out of live working on LV and MV networks was additionally encouraged. An outstanding example of calculation of viability of live working in the German distribution company E.on in the LV and MV networks and overhead lines and transformer stations is presented. Dütsch [6] pointed out that individual live working activities were less expensive than the work in a deenergised condition.

A reduction in SAIDI by 11 minutes/year was achieved because of carrying out live working and a regulator's bonus was obtained at the annual level. The regulator prescribed a new formula that has been used for the calculation of the annual revenue since 2012. The formula contains the quality element Qt by means of which the bonus/malus for an individual distribution network is regulated within $4 \%$. The first result of the efficiency of German distribution networks in meeting the requirements of the regulator is presented for the 202 ODS (bonus for 143 ODS and malus 59 for ODS) [6].

\section{Conclusion and future research}

In spite of a hundred year development and carrying out of live working practically all over the world and especially in Europe, live working has got a new incentive by the liberalisation of the electricity market. Very clear requirements of the national regulators increase the pressure on the operators of transmission and distribution networks for the achievement of higher standards of quality of electricity and/or quality of electricity supply $[5]$.

The current world development trends in the field of live working have still been traditionally focused on the fields of technology of carrying out live working, development of new tools and personal protective equipment and training in live working at all voltage levels, which was confirmed in the last professional and specialised conferences (ESMO - IEEE, 2011; CITTES, 2013; ICOLIM, 2014).

When reviewing the expert papers prepared for professional conferences it can be established that the industry deals mainly with live working in transmission and distribution. Therefore, there exists a large gap in the discussions of introduction and carrying out of live working and its advantages beyond the electricity sector, i.e. in industry and institutions (hospitals, infrastructure) and households.

Slovenia is a rare exception, as carrying out of live working since 2009, initially started on LV networks in industry and production of electricity, and only later in transmission and distribution $[4,19]$.

Safety is one of the basic objectives when carrying out the maintenance works / preventive maintenance and implementing maintenance concepts of CBM, RCM, TPM and TQMain.

Al-Najjar [21] claims that TPM and TQM have a common axis, an important and strong driver, where improvements and/or the Deming PDCA cycle are repeated. He established that the PDCA cycle is suitable for the use immediately upon the occurrence of a failure. The usefulness of the PDCA cycle can be expected also at an early stage, e.g. immediately when significant deviations from standard operating characteristics of the equipment/process (e.g. early diagnosis of a paper machine by the VBM method) are established.

Live working has been mainly discussed as a service that has been introduced and carried out as a competitive advantage in the organisations and companies that will be able to adjust and offer a higher level of quality services to their customers of electricity. Quality is actually one of the basic criteria according to which organisations are evaluated [41].

One of the important criteria of the quality of electricity is the reliable supply and/or the continuity of electricity supply. Public agencies and/or national regulators or the Agency of the European Union annually report on the SAIDI / SAIFI indicators and require and penalise the lower level of achieved quality of electricity than prescribed by their measures [6, 29]. 
The organisations with the integrated management system have excellent organisational environment for a safe introduction of live working [25] and can pursue the "zero defect" [42] and "zero accident" or "zero injury" at work objectives because of an electric shock [35].

On the basis of the prescribed requirements of the German energy regulator from the year 2012 the paper [6] clearly outlines the direction of live working development in distribution networks, as it has proved that the prescribed conditions of quality of electricity cannot be met without live working on LV and MV installations.

When studying the specialised literature on live working it has been established that there are gaps in the research of live working as a tool of preventive maintenance. And therefore it is of great importance that research is continued as it should give answers to the following questions:

- Does carrying out of maintenance of electrical installations by the live working method have an impact on meeting the requirements of customers for electricity and higher level of quality of electricity?

- Does carrying out of maintenance of electrical installations by the live working method reduce the number of accidents at work with electricity?

- Does carrying out of maintenance of electrical installations by the live working method contribute to better effectiveness and efficiency when carrying out preventive maintenance of electrical installations?

The results of our research in progress where we focus on the thesis that "By upgrading the processes of maintenance with the live working method the quality, compliance with the requirements for safety and health at work as well as effectiveness and efficiency in the maintenance of electrical installations improve" might be of interest to a broader live work community.

\section{Acknowledgements}

We would like to thank the organisers of ICOLIM 2014 who gave us all the papers published from the $1^{\text {st }}$ to the $11^{\text {th }}$ ICOLIM conference in the period 1992-2014.

We would also like to thank the Managing Director of RTE SERECT Mr. Luis Devetine who presented us the English version of the book "Live working a cutting edge technique, 50 years of French history" (RTE SERECT, 2014) in Budapest.

\section{References}

[1] Live working a cutting-edge technique. 50 years of French history. // RTE SERECT. Photogravure Planete Couleurs, Paris, 2014.

[2] Looms, J. S. T. Live working on high-voltage lines. // IEEPROC. 128, 2(1981). https://doi.org/10.1049/ip-a-1.1981.0012

[3] Lubicki, W.; Dudek, B. Eighty years of Polish experience in technology of live-line working and impressions from all 10 ICOLIM conferences. // Proceedings of $11^{\text {th }}$ International Conference on Live Maintenance, ICOLIM 2014 / Budapest, 2014. https://doi.org/10.1109/ICOLIM.2014.6934327

[4] Pirc, M.; Lovrenčić, V. Experience with live work (LW) implementation in nuclear power plant KRŠKO (NEK).
// Proceedings of $10^{\text {th }}$ International Conference on Live Maintenance, ICOLIM 2011 / Zagreb, 2011.

[5] Live Work - A Management Perspective. // Technical Brochure No. 561. Joint Working Group B2/B3.27 (JWG 27), CIGRE. Paris, 2013.

[6] Dütsch, K. Quality Regulation in German Distribution Networks - New Impulse for Live Working. // Proceedings of $11^{\text {th }}$ International Conference on Live Maintenance, ICOLIM 2014 / Budapest, 2014. https://doi.org/10.1109/ICOLIM.2014.6934390

[7] SIST EN 50110-1:2004 - Obratovanje električnih inštalacij.

[8] Live Work Guide for Substations. // Research report No 1008746, EPRI. Palo Alto, 2004.

[9] Garfinkel, P. Live work. // EPRI Journal, September/October (1995), pp. 14-19.

[10] Laugier, M.; Devatine, L.; Jouglard, J. P. RTE and Live Substation Work at Powerlink Queensland. // Proceedings of $11^{\text {th }}$ International Conference on Live Maintenance, ICOLIM 2014 / Budapest, 2014. https://doi.org/10.1109/ICOLIM.2014.6934345

[11] Stix, G. Working hot life at $765 \mathrm{kV}$. // IEEE Spectrum, September 1988, pp. 54-56. https://doi.org/10.1109/6.7169

[12] Simões, F.; Craveiro, J. Live Line Dry Cleaning in Electrical Installations. // Proceedings of $10^{\text {th }}$ International Conference on Live Maintenance, ICOLIM 2011 / Zagreb, 2011.

[13] Barbieri. L.; Malgesini, R.; Villa, A.; De Donà, G.; Milanello, C. D.; Zanotti, A. Insulated aerial vehicles and high voltage live working in Italy: tests and studies to assess the safety aspects. // Proceedings of $11^{\text {th }}$ International Conference on Live Maintenance, ICOLIM 2014 / Budapest, 2014. https://doi.org/10.1109/ICOLIM.2014.6934343

[14] Elizondo, D.; Candia, H.; Kruimer, B. Ground based robots for transmission line work-technology description, international field project applications and economic benefits. // Proceedings of 10th International Conference on Live Maintenance, ICOLIM 2011 / Zagreb, 2011.

[15] Riquel, G.; Oury, N. Influence of floating objects on the dielectric strength. // Proceedings of $10^{\text {th }}$ International Conference on Live Maintenance, ICOLIM 2011 / Zagreb, 2011.

[16] Schau, H. The New ISSA Guideline for the Selection of Personal Protective Equipment when Exposed to the Thermal Effects of an Electric Fault Arc. // Proceedings of $11^{\text {th }}$ International Conference on Live Maintenance, ICOLIM 2014 / Budapest, 2014. https://doi.org/10.1109/ICOLIM.2014.6934362

[17] Göcsei, G.; Németh, B.; Kiss, I.; Berta, I. Health Effects of Magnetic Fields during Live-Line Maintenance. // Proceedings of $11^{\text {th }}$ International Conference on Live Maintenance, ICOLIM 2014 / Budapest, 2014. https://doi.org/10.1109/ICOLIM.2014.6934329

[18] Caha, V. Usporedna analiza radnih postupaka RPN i u beznaponskom stanju u HEP ODS-u. // Specijalistički rad, Osijek: Sveučilište Josipa Juraja Strossmayera, Elektrotehnički fakultet, 2012.

[19] Lovrenčić, V.; Brezavšček, A.; Pantoš, M.; Gomišček, B. Uspešni začetki izvajanja dela pod napetostjo in možni učinki pri vzdrževanju distribucijskega omrežja. // Proceedings of $12^{\text {th }}$ conference of Slovene electricity experts CIGRE - CIRED / Portorož, 2015.

[20] Maletič, D.; Maletič, M.; Gomišček, B. Podpora odločanju managementu $\mathrm{v}$ procesih vzdrževanja. // Proceedings of $20^{\text {th }}$ conference Tehniško posvetovanje vzdrževalcev Slovenije, Vzdrževalec, 137 (2010), pp. 52-57.

[21] Al-Najjar, B. Condition-based maintenance: Selection and improvement of a cost-effective vibration-based policy for rolling element bearings. // Doctoral Thesis, Lund: Lund University, Lund Institute of Technology, 1997. 
[22] Nakajima, S. Introduction to Total Productive Maintenance (TPM). // Productivity Press. Cambridge, 1988.

[23] Lovrenčić, V.; Habjan, R.; Lušin, M. Uvajanje dela pod napetostjo $\mathrm{V}$ slovenskem papirništvu: primer Papirnica Vevče. // Proceedings of $3^{\text {rd }}$ International Annual Symposium DITP / Bled, 2010.

[24] Portillo, M. Live working as an example of excellence in the management of electricity networks. // Proceedings of $10^{\text {th }}$ International Conference on Live Maintenance, ICOLIM 2011 / Zagreb, 2011.

[25] Lovrenčić, V.; Oman, V. Nadgradnja sistema managementa kakovosti ISO 9001:2008 z zahtevami za izvajanje dela pod napetostjo. // Proceedings of $31^{\text {st }}$ International Conference on the development of organisational sciences - Quality. Innovations. Future. / Portorož, 2012.

[26] Delince, J. M.; Delhove, B., Cossement, M. Substation Live Working in Belgium. // Proceedings of $2^{\text {nd }}$ International Conference on Live Maintenance, ICOLIM 1994 / Mulhouse, 1994.

[27] Portillo, M.; Fernández, L. J.; Andrés, A. Field experience in live working at RED Electrica de Espana. // Proceedings of $4^{\text {th }}$ International Conference on Live Maintenance, ICOLIM 1998 / Lisbon, 1998.

[28] Kovacs, G. Impact of live working activities on the service quality indices. // Proceedings of $7^{\text {th }}$ International Conference on Live Maintenance, ICOLIM 2004 / Bucharest, 2004.

[29] 5th CEER Benchmarking Report on the Quality of Electricity Supply. // Council of European Energy Regulators, CEER. Brussels, 2012.

[30] Mrakovčić, B.; Rad pod naponom. // Energija, 29, 1112(1980), pp. 443-450.

[31] Report of UNIPEDE Live Working Correspondents Group. // UNIPEDE, 1991.

[32] Dudek, B.; Maslyk, E.; Wlsniewski, W.; Wojcik, M. Développement des travaux sous tension sur les réseaux électriques en Pologne. // Proceedings of $1^{\text {st }}$ International Conference on Live Maintenance, ICOLIM 1992 / Keszthely, 1992.

[33] Moreno, D. A.; Viadas D. J. Accidentalidad en trabajos en tensión prevención-protección - Accident rate in voltage works. // Proceedings of $5^{\text {th }}$ International Conference on Live Maintenance, ICOLIM 2000 / Madrid, 2000.

[34] McDermid, W.; Swatek, D. R.; Bromley J. C. FRP Hot Stick Flashovers during EHV Live Line Work. // Proceedings of 2003 ESMO, $10^{\text {th }}$ International Conference on Transmission and Distribution Construction and LiveLine Maintenance / Orlando, 2003. https://doi.org/10.1109/EICEMC.2003.1247844

[35] Andersson, O.; Olsson, G. Live-line working in the Nordic Transmission Grids. An assessment of the technical and economic conditions. // Report R07-397, STRI. Ludvika, 2007.

[36] Lovrenčić, V.; Gomišček, B. Live Working as an Example of Electrical Installation Maintenance with the Zero Accidents Philosophy. // Proceedings of $11^{\text {th }}$ International Conference on Live Maintenance, ICOLIM 2014 / Budapest, 2014. https://doi.org/10.1109/ICOLIM.2014.6934344

[37] Quanta Energized Services maintains a "zero tolerance" safety policy. // QES. The web version (2014), http://www.quantaenergized.com/safety. (17.08.2015)

[38] Kiener, A. Valorisation of planned outrages in the transmission Network. // Proceedings of $2^{\text {nd }}$ International Conference on Live Maintenance, ICOLIM 1994 / Mulhouse, 1994.

[39] Van Merris, X.; Paquin, J.; Debackere, A.; Cossement, M. First results of live working realised in Belgium in high voltage substations. // Proceedings of $4^{\text {th }}$ International
Conference on Live Maintenance, ICOLIM 1998 / Lisbon, 1998.

[40] Antoine, J. C. Live Line Working at Middle Voltage 'Three Method' Technique. // Proceedings of $1^{\text {st }}$ International Conference on Live Maintenance, ICOLIM 1992 / Keszthely, 1992.

[41] Marolt, J.; Gomišček, B. Management kakovosti. Moderna organizacija, Kranj, 2005.

[42] Crosby, P. B. Quality is free, The art of making quality certain. McGraw-Hill, New York, 1980. (Translation Kakovost je zastonj, Umetnost zagotavljanja kakovosti. ČGP DELO, Ljubljana, 1989).

\section{Authors' addresses}

Viktor Lovrenčić, $M S c$

C \& G d.o.o. Ljubljana

Riharjeva 38, 1000 Ljubljana, Slovenia

viktor.lovrencic@c-g-si

\section{Alenka Brezavšček, PhD}

University in Maribor, Faculty of Organizational Sciences Kidričeva cesta 55a, 4000 Kranj, Slovenia alenka.brezavscek@fov.uni-mb.si

\section{Miloš Pantoš, PhD}

University in Ljubljana, Faculty of Electrical Engineering Tržaška cesta 25, 1000 Ljubljana, Slovenia milos.pantos@fe.uni-lj.si

\section{Boštjan Gomišček, PhD}

University of Wollongong in Dubai, Faculty of Business Block 15, Knowledge Village, P. O. Box 20183, Dubai, UAE BostjanGomiscek@uowdubai.ac.ae 